\title{
POSSIBLE BAR-TAILED GODWIT IN SASKATCHEWAN
}

PAUL ALLEN, 43 Beechwood Avenue, Locking, Nr Weston-super-Mare, Avon. BS24 8DS. England.

On 28 July 1983 there was a single godwit on the northeast shore of Porter Lake near Aberdeen, Saskatchewan. Using a 25-50x60 telescope on a tripod, I viewed the bird stationary in shallow water for approximately 12 minutes at a range of about $20 \mathrm{~m}$. I made no detailed notes at this time. Following is a description based on notes taken about 1 hour after seeing the bird.

\section{Description}

The bird was of the same size as Hudsonian Godwit with a long slightly upturned bill.

Plumage of the head and neck were dull reddish, with colour extending down breast to lower belly. Under tail coverts were whitish. The tail was white with black transverse bars. Upper parts were very dark, the wing similar except for the primares, which were darker.

Eventually this godwit flew north towards the end of the lake. In flight the following features were noted: indistinct thin whitish wing bar, slightly more distinct on secondaries; tail white with transverse black bars; rump white, extending up back in a dowitcher-like $V$.

\section{Discussion}

I am familiar with this species in England in winter (fall) plumage and to a lesser extent in summer (spring) plumage. Though the structure was consistent with the species seen in Britain, the Bar-tailed Godwit in England is more orange or buffier in my experience, with the upper parts browner and not so dark as this bird's. The British Bar-tailed Godwit shows no trace of a wing bar; however I have not noticed this specifically on spring birds.

Assuming Bar-tailed Godwits are the same worldwide, it would appear that this bird showed characteristics of both Bar-tailed and Hudsonian Godwit. It resembled Bar-tailed in having red on the head and neck as well as breast and belly, a transversely barred white tail and white rump extending up the back in a $V$. The indistinct wing bar would appear to be an intermediate condition between the two species. It resembled Hudsonian Godwit in the colour of the red plumage and that of the upper parts.

There would seem to be 3 possibilities: (i) it was a Bar-tailed Godwit; (ii) it was a mutant Hudsonian Godwit; (iii) it was a hybrid Hudsonian-Bar-tailed Godwit.

I am not familiar with the plumage of eastern palearctic or western nearctic birds of this species." It would not seem likely that a single gene mutation could account for the extent of the observed differences from Hudsonian Godwit. I understand that Hudsonian Godwit breeds locally in Alaska. Could this bird have been a hybrid Hudsonian-Bar-tailed Godwit?

\section{Summary}

My initial identification was based on the extent of red (reaching head and neck), the tail pattern (barred), the 
white rump and back. I did not think the colour of the red or the upper parts was critical, nor pointed towards Hudsonian Godwit. Peterson's Field Guide to Western Birds depicts Bar-tailed Godwit as having an indistinct wing bar consistent with the bird seen at Porter Lake.
* EDITOR'S NOTE: The Bar-tailed Godwit that breeds in Alaska is reported to have a "poorly defined wing stripe" (R. H. Armstrong. 1980. A guide to the birds of Alaska. Alaska Northwest Publishing Co., Anchorage). In The birds of Canada, Godfrey mentions a single Canadian specimen from British Columbia.

\section{EARLY FLEDGING RECORD OF WESTERN MEADOWLARK IN MANITOBA}

MARTIN K. MCNICHOLL, 320 Markham Street, Toronto, Ontario. M6G 2K9

On 26 April 1969, while helping Robert J.Brown cannon-net SharptailedGrouse at Hodgson, Manitoba, we set a largemesh mist net at the edge of the grouse "dancing ground" to capture grouse that flushed before the cannon net landed. After one firing, we found a recently fledged Western Meadowlark in the net. The meadowlark had the general adult plumage markings, but these were not yet in full colour and the black $V$ was not yet well defined. The bird could fly only a few metres at a time. Since I did not have the correct band size for meadowlarks with me, I photographed the bird and released it.

Lanyon gave incubation periods for seven Western Meadowlark nests as 13 to 16 days, and Bent cited two earlier sources as stating 13 or 15 days. $^{3}{ }^{10}$ Bent quoted Dawson and Bowles as stating that Western Meadowlark young may leave the nest four or five days after hatching, but this is likely only in response to disturbance. ${ }^{3}$ Skaggs observed young from a nest of the Eastern Meadowlark to leave the nest 14 days after hatching, when they were "not able to fly 10 feet," a stage probably comparable to the Manitoba bird. ${ }^{25}$ Taking 14 days as a typical fledging period and adding a minimum incubation period of 13 days, the fledgling that we caught on 26 April must have been from a nest in which incubation started no later than 30 March, and probably a few days earlier.

Of 14 Manitoba records gleaned from the literature(Table 1), only one reports nesting in April. Similarly, nesting dates reported on 40 cards from Manitoba in the Prairie Nest Records Scheme ranged from 17 May to 22 July (Tab/e 2). Nesting dates for other provinces and states in the Northern Great Plains are comparable. For example, Bent listed egg 